\title{
Of Yellow Teaching and Black Faith: Entangled Knowledge Cultures and the Creation of Religious Traditions
}

\begin{abstract}
The spread of Tibetan Buddhism to the Mongolian regions in the late sixteenth century did not only result in often violent confrontations between Tibetan Buddhist monks and Mongolian religious specialists, the male and female shamans, but also led to a reification process of local religious practices and concepts resulting in the creation of a single tradition on the discourse level. In my paper I will show how the 'teaching of the shamans' has come to be formed as both a concept and a practice in early-modern Inner Asia. By analyzing its discursive formation and entangled historical configurations, from late sixteenth century Mongolia to late nineteenth century Buryatia, the paper aims to shed light on the question how religious traditions are discursively created and socially affirmed.
\end{abstract}

Keywords: 'teaching of the shamans', Tibetan Buddhism, Mongols, Buryats, šasin, böge mörgöl, Shamanism, global history of religion, entangled history, religious traditions

\section{Introduction}

Sometime in the first decades of the seventeenth century, the Mongolian Buddhist monk Neyiči Toyin ${ }^{1}$ traveled in nowadays Eastern Mongolia, using his healing powers and magical abilities to convert the Mongols to the 'Yellow Teaching', the dGe lugs pa-form of Tibetan Buddhism. His hagiography, entitled Garland of wish-fulfilling jewels (Mo. Čindamani-yin erike), written nearly a century later, tells us about the reaction of the indigenous religious specialists, the shamans, when they heard that Neyiči Toyin was approaching their region:

1 The classical Mongolian is rendered according to Rachewiltz 1996, with the exception of the letter $j$ which is given without the haček. For well-known Tibetan and Mongolian terms, however, I use the popular spellings, thus 'Dalai Lama' instead of 'Dalai Blama'. The Tibetan is transliterated according to Wylie, Sanskrit is transliterated according to the internationally accepted rules.

DOI 10.1515/9783110450934-013, (c) BY-NC-ND (c) 2017 Karénina Kollmar-Paulenz, Published by De Gruyter. This work is licensed under the Creative Commons Attribution-NonCommercial-NoDerivs 3.0 License. 
[...] these shamans talked to each other: 'From the western direction a very powerful lama is coming. Upon his arrival there will be no place where he can stop and rest, so, when he calls on us, we will not come' (Prajñasagara 1739, fol. 53r-53v).

The text suggests that in their refusal to meet the Buddhist monk the shamans acted as a unified social body. This information is contrary to all historical knowledge about shamans. In historical Mongolian communities male and female shamans were ritual specialists who were individually called by the spirits and who acted on their own. We do not have any historical evidence of 'shamanic associations' or any kind of institutional shamanic organization in the Mongolian territories other than the short passage I just quoted. Why, then, are the shamans treated in our source as a compact social body?

Another case: In the late seventeenth century the Kangxi emperor of the newly established Qing dynasty in China had successfully integrated the Mongols of Inner and Outer Mongolia into his empire. Subsequently, the Qing dynasty promoted 'inner peace' in the outer regions of the Empire by legal measures. The first law code to be commissioned by the Qing was the so called 'Mongol law code of the Kangxi Era' (1662-1722), published sometime after 1694 (Heuschert 1998, 46-50). This law code, of all in all 152 articles, contains one article on the community of the Buddhist lamas and the community of the male and female

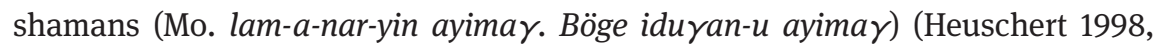
215-216 [fol. 39v-41r]). The article lays down the punishments administered to lamas and shamans who do not follow the socio-religious injunctions (Mo. yosun) of their respective communities. The Qing administration thus dealt with the highly individual indigenous religious specialists of the Mongols in the same way as they dealt with the Buddhist monks. They treated both as social groups and as juridical bodies.

Actually, it was this law code that a couple of years ago made me aware of the rigorous reification process the Mongolian male and female shamans were subjected to and which led to the discursive formation of a religious tradition called in translation 'teaching of the shamans' (Mo. böge-ner-ün šasin) or 'veneration of the shamans' (Mo. böge mörgöl) in seventeenth century Mongolia, long before the 'shamanism paradigm' was formulated in Enlightenment Europe (Kollmar-Paulenz 2012). Shamanic practices and shamanic imagery have been and are, despite the strong influence of global neo-shamanism, not a coherent system, but rather a collection of representations, which can appear at different places and be employed in various ways (Humphrey 1999, 192). Their fluidity defies standardization. Even today, they are best studied in their particular social settings in contexts of local power relations. Notwithstanding that, in late sixteenth and early seventeenth century Mongolia we can observe how these 
local ritual practices that were performed by particular religious specialists were gradually turned into an abstract, homogeneous and ahistorical entity by subsuming them under a generic terminology that discursively identified a specific field of social interaction and was articulated mainly in antagonistic categories (Kollmar-Paulenz 2013, 167-173). In the following, I will explore how this standardized and stable religious tradition of 'shamanism' was established and naturalized in early-modern Mongolia and shaped people's perception of social reality. I hope that a closer look at the discursive formation of Mongolian 'shamanism' will help to shed light on the general question how religious traditions emerge and are established. To this aim, after some short remarks on my conceptual approach, I will first focus on the events that led to the Buddhist transformation of the Mongolian religious landscape in the late sixteenth century. Secondly, I will examine the discourse that accompanied and shaped this transformation and led to the construction of a reified system of 'shamanism'. The third part of this chapter concentrates on the Buryat-Mongols and analyzes the changes the discourse on the 'teaching of the shamans' underwent under Russian-European influence in the nineteenth century.

The discursive creation of a 'teaching of the shamans' touches on one particular aspect in recent theoretical debates in Religious Studies, the relation between Non-European and European knowledge systems. If one is familiar with the Mongolian configuration of the 'teaching of the shamans' and early key texts like Dorji Banzarov's highly influential The Black Faith or Shamanism among the Mongols, first published in 1846 and to this day one of the classics in shamanism research (Banzarov 1846), it is impossible to ignore that the European debate about shamans was influenced by the Mongolian discourse. Up to now, however, this goes mainly unnoticed in scholarship. Although postcolonial theory explicitly acknowledges, in the words of Robert Young, 'that the intellectual and cultural traditions developed outside the west constitute a body of knowledge that can be deployed to great effect against the political and cultural hegemony of the west' (Young 2010, 65), the debate still privileges Western knowledge systems, often to the exclusion of their non-Western counterparts. Indeed, scholarly opinion has shifted from the assertion of the complete silence of native voices to what Charles Hallisey has called the 'intercultural mimesis': that is, 'aspects of a culture of a subjectified people influenced the investigator to represent that culture in a certain manner' (Hallisey 1995, 33). And yet, the history of those 'aspects of a culture' in their own contexts and networks of relations and interactions is still ignored. All too often, non-European knowledge cultures seem to emerge out of their obscurity and come into existence only in their relation and response to the encounter with Europe, in the process losing their own historical legacy. In this way, the stereotypes of an active, theory-producing West 
and a passive, theory-consuming non-West, are continued rather than abandoned.

We may ask ourselves whether it is still promising to follow theoretical models into which unquestioned dichotomies of the European 'self' and its 'other' are inscribed. With regard to a global history of religion (Kollmar-Paulenz 2010, 265268. 274-275; Bergunder 2011, 50 -55; Kollmar-Paulenz 2013, 185-187), it could be more fruitful to undertake a radically new positioning, to do a new survey of the religious landscapes and to draw new maps that no longer privilege Europe as the beginning and end of the history of religions, to explore new spaces and historical entanglements. To realize such an endeavor, Religious Studies could (and indeed has already started to do so) probe into approaches that are used in Global History Studies, particularly the concept of history as an 'ensemble of entanglements' (Conrad, Randeria 2002). Writing history as entanglement entails taking the many interactions of different world regions as a starting point for a transnational historiography that concentrates on the de-centralized character of global entanglements. Intimately connected to, or indeed a special focus of, a Global History perspective, an entangled history approach does not treat the subjects of historical examination as stable, given entities, but as manmade constructions into which specific mechanisms of power are inscribed. This approach no longer allows for a fixed, regional-geographic center or a privileged subject, and opts for a 'co-equalness' with regard to epistemic cultures. ${ }^{2}$ It stresses the fundamental role that the interactions between different regions of the world have played for the formation of a global modernity. ${ }^{3}$

Extending the entangled history approach to religious cultures, I will examine the respective interactions and entanglements of the Tibeto-Mongolian Buddhist cultural regions. My main geographical focus will thus be on Tibet, Mongolia, China and Russia. To counteract the still unsolved problems of this approach which I see mainly in the terms and taxonomies we use for analysis and which are all taken from a European intellectual context, ${ }^{4}$ I will combine the entangled history approach with a micro-historical analysis, in which special attention will be paid to local dynamics and concrete historical spaces.

Methodologically, this contribution is situated in historical discourse analysis that asks about the ways how in the historical process knowledge is produced (Landwehr 2008). I rely on a variety of individual Mongolian and Tibetan sources

2 Compare Chakrabarty 2000, 29.

3 One illuminating case-study is provided by van der Veer 2001.

4 For the problem of the universal use of historically particular analytical categories and theories see Pernau 2007. 
that belong to different literary genres: historical chronicles ${ }^{5}$ and biographies; ${ }^{6}$ colophons of the Mongolian Buddhist canon (Mo. Ganjuur) (Ligeti 1942; Kas'yanenko 1993; Siluyun budayun üye onoqui neretü sudur); ritual texts, both Buddhist and non-Buddhist (Heissig 1992; Chiodo 2009); legal documents (Heuschert 1998; Bajarsajchan 2004), and bi-lingual terminological dictionaries (Dag yig mkhas pa’i byung gnas; Ye shes rdo rje 1959). This heterogeneous corpus of texts allows me to follow the dynamics of the discourse in different segments of the historical realities it produces. The sources span a time period of roughly three hundred years, the earliest having been written around the year 1600, the most recent in the last decade of the nineteenth century. They have their origins mostly in the Inner and Outer Mongolian regions that during that period were part of the Manchu-Chinese Qing Empire, and nearly all of them are written by Buddhist authors. For the nineteenth century, I also draw on Buryat-Mongolian historical chronicles (Toboyin 1863; Yum Čüng 1875). The Buryats were subjects of the Russian Empire, a fact which did have a significant impact on the formation of their knowledge systems, as we will later see.

\section{The Mongols turn Buddhist}

When in 1578 the then most powerful ruler in the Mongolian steppes, Altan Qayan of the Tümed Mongols, and the Tibetan Buddhist monk bSod nams rgya mtsho, the later Third Dalai Lama, met at the temple of Čabčiyal at Kökenor lake, their meeting marked the beginning of the Buddhist domination of the Mongolian regions (Sagaster 2007). Soon after the meeting of the ruler and the monk, Tibetan lamas began to spread the dharma, the Buddhist teaching, among the different Mongolian peoples, and within a time span of not much more than fifty years the Mongols had nearly completely taken up Tibetan Buddhist concepts and practices and were effectively Buddhicized. Only in the adjacent regions of nowadays Buryat-Mongolia this process slowed down and Buddhism took root in these regions as late as the eighteenth century. The historic meeting did not only lead to the formation of a new social class in Mongolian societies, the Buddhist sangha, that was politically put on a par with the Mongolian nobility, but also brought about the - at first glance - thorough Buddhist

5 Vanchikova 2001; Anonymous 1607; Haenisch 1955; Anonymous $18^{\text {th }}$ century; Anonymous 1980; Lubsandanjin 1655; Byamba Erke Dayičing 1677; Siregetü Guosi Dharma 1739; Rasipungsur 1774/75; Jimbadorji 1834-1837.

6 Prajñasagara 1739; Bawden 1961; Kämpfe 1976a; Kämpfe 1976b; Kämpfe 1977; Kämpfe 1979a; Kämpfe 1979b. 
transformation of the Mongolian religious landscape. This landscape was characterized by a multiplicity of local religious practices that were grounded in and at the same time constituted a specific perspectivist ontology that has recently been coined as 'transcendental perspectivism' (Holbraad, Willerslev 2007). Mongolian baizal, 'nature' that is not separate from but includes human beings, is envisaged as vibrant with entities that have their own 'majesty' (Mo. sür) or effectiveness (Mo. čadal) which is simply there (Humphrey 2003, 136). Shamans receive their power from these energies which are often visualized as spirits (Humphrey 2003, 151). Framed in a narrative of the clash of two opposing world views, the Buddhist encounter with these local religious specialists was in many aspects a battle for social and political authority. The Buddhist monks were quick to challenge the authority of the dominant Mongolian religious specialists, the male and female shamans. They had on their side the Mongolian rulers and the nobility who actively sought to implement the new religion among their subjects. The local rulers in late sixteenth century Mongolia issued laws that prohibited shamanizing and those religious practices related to it (Haenisch 1955, fol. 77r). Such practices included the worship of the Ongrod, the powerful ancestor spirits and spiritual helpers of the shamans, and blood sacrifices. However, the rituals and practices that belonged to every-day socio-religious life, like the worship and cult of the mountain, the fire cult or the veneration of the hearth deity, as well as the various groups of gods, demons and spirits believed to enliven the world, were not forbidden, but gradually transformed and incorporated into Buddhist practices and beliefs. ${ }^{7}$

Local rulers prohibited the practice of shamanizing, and also actively persecuted the male and female shamans, as the Mongolian biography of Altan Qayan, entitled 'Sūtra named "precious clearness"' (Mo. Erdeni tunumal neretü sudur), suggests:

After they had set on fire the outer Ongrod images, they weakened and eliminated the ecstatic and ignorant male and female shamans (Anonymous 1607, fol. 29r).

The burning of the Ongrod, the spirit-helpers of the shamans and thus of highly symbolic value, is reported in our Mongolian and also some Tibetan sources (Ngag dbang blo bzang rgya mtsho 1984, 148). The destruction of the Ongyod and other shamanic paraphernalia, like the clothes or the drum, contributed to the growing invisibility of shamanic representations in the social field.

7 See the Collected Works of the Third Mergen Gegen (1717-1766) (Mergen Gegen 2006) who among his many writings composed Buddhist texts for local spirits (Humphrey, Ujeed 2013, 187). 
The secular authorities did not only try to put an end to the activities of the shamans by purges and by law, but also bribed the people into performing Buddhist rituals. According to the Garland of wish-fulfilling jewels the ruler of the Qorčin Mongols in Eastern Mongolia publicly proclaimed material rewards, for example a cow or a horse, if the local people learned to recite Buddhist formulas (Prajñasagara 1739, fol. 46v). Moreover, the monks themselves employed this method to win people over, as the same source reports (Prajñasagara 1739, fol. $74 \mathrm{r}-74 \mathrm{v})$.

While the central Qing government did not actively persecute the shamans, the imperial policy of supporting the Mongolian Buddhist institutions indirectly contributed to the social marginalization of the shamans in the Mongolian societies. The success of this reconfiguration of Mongolian social reality is again transparent in the legislation: the article about the lamas and the shamans was annulled at a later date in favor of a new article which, however, only addressed the lamas (Bajarsajchan 2004, 224-229; Heuschert 1998, 136-137). From then on, the shamans were rendered invisible in the Qing law codes.

\section{Creating a new religious tradition: The 'false view of the male and female shamans'}

The Buddhist advent in Mongolia was accompanied by a narrative that established Buddhism as the 'true teaching' and the shamanic practices as the 'false view' (Mo. buruyu üjel). In a text fragment about the ritual repelling of bad omens found in Xarbuxyn Balgas and dating around the year 1600 (Chiodo 2009, 182), I came upon the first such statement that singled out shamans as a distinct social group and attributed to them a specific world-view. The appellation bururu üjel-tü böge iduran, 'male and female shamans possessing a false view', was often used in direct opposition to burqan-u šasin, the 'teaching of the Buddha', as the following example illustrates:

In this way, the false view [of the shamans] was brought to its end, and the teaching of the Buddha emerged pure and clear (Prajñasagara 1739, fol. 54r).

The network of concepts used to articulate this narrative and the normative assumptions underlying it are part of the Indo-Tibetan knowledge systems. Mongolian buru zu üjel translates the Tibetan term lta log ('aberrant view') which in a Tibetan Buddhist context usually denounces controversial doctrinal views and thus an alleged erroneous understanding of the dharma and its practice. This philosophical terminology belongs to a broader inner-Buddhist discourse 
about philosophical doctrines and their soteriological values (Lopez 1996). Thus, the Mongolian use of buruzu üjel confirms an inner-Buddhist discourse about the religious 'other'. Its application illustrates the reifying processes in the Buddhist discourse of the time with regard to the shamans and shows that their practices were judged from a normative and exclusivist Buddhist viewpoint. The terms employed, üjel, '[world]view', and nom, 'teaching' (in the statement yadayadu nom, 'outer teaching'), are associated with concepts and practices that are considered karmically wrong, like blood sacrifices. ${ }^{8}$ However, in the communicative process of translation, the Tibetan philosophical term and concept of $l t a \log ^{9}$ was subtly accommodated to the Mongolian context. The semantic field of Mongolian üjel, 'the act of seeing, beholding, view, conception' stresses the notion of the individual as interdependent part of the community and the role visuality plays in the individual's relationship with the group. In contrast to the Tibetan concept of lta $b a$ which focuses on philosophical expositions, the discourse structured by the semantic field of üjel emphasizes the role of the actors and their performance, as well as their emotional and intellectual responses to seeing and being seen.

The attribute 'male and female shamans' designates the actors of the 'false view' who in the narratives are recurrently represented as 'morally bad' (Mo. mayu), as fake-healers and evil sorcerers. This personalization gives us an important clue about the structural aspect that allowed the Tibetan monks to include the male and female shamans in the same social field of interaction as themselves and thus ascribe a common generic taxonomy to them. Their activities are described in competition to the Buddhist monks: they performed publicly as healers and exorcists for the benefit of their communities. Such activities have not only been the main field of interaction for shamanic practitioners, but also for many Buddhist religious practitioners that are subsumed under the Tibetan generic term chos $p a$, 'people who are expert of religious practice', as a Tibetan dictionary explains (Zhang Yisun 1985, 840). Many Tibetan monks are very apt at employing rituals and practices primarily aimed at healing and divination, at exorcizing and conjuring up evil forces. The Mongolian Bud-

8 See, for example, the extensive discussion about the 'aberrant cutting' (Tib. gcod log) practice in Khams smyon 'Jigs bral chos kyi seng ge 1974, fol. 70v-74r. An aberrant view necessarily leads to an aberrant practice: the author accuses the practitioners of the 'aberrant cutting' of cannibalism and the use of drugs (fol. 70v).

9 The dGe lugs pa-understanding of 'aberrant view' which is also valid in the Mongolian Buddhist context includes 'a denial of cause, effect, functionality, and existent phenomena' (Hopkins 1983, 260-261). The 'aberrant view' is one of the five 'afflicted views' (Tib. lta ba nyon mongs can) which build one of the six root afflictions according to the dGe lugs pa Prāsangika-Mādhyamika philosophy (Hopkins 1983, 256). 
dhist sources are full of stories in which a Buddhist lama competes with a shaman in healing a sick person. The Garland of wish-fulfilling jewels reports the particularly impressing story of an old blind female shaman who is healed by the famous Buddhist missionary Neyiči Toyin and in the aftermath 'the shamaness worshipped with true and sincere faith' (Prajñasagara 1739, fol. 44r). The shamans occupied the same social role and function as many a Buddhist monk, and were thus categorized according to their social function.

Yet other taxonomies, not all of them stressing differences, structured the emerging discourse about 'the teaching of the shamans'. In Mongolian texts of the seventeenth and eighteenth centuries the terms šasin mörgöl for 'Buddhism' and böge mörgöl for 'Shamanism' were used. Mongolian mörgöl literally denotes 'the act of bowing', stressing the bodily performance of venerating the dharma or, respectively, the shamans. Both terms emphasize the visible and performative aspects of the Mongolian embodied construction of 'religion'. Perhaps the most important reason for the rapid Buddhist transformation of the Mongolian societies lies exactly in the fact that the Mongols and the Tibetans shared a very similar socio-religious habitus. The habitus, as Bourdieu has shown, cannot become subject to reflection without being distorted. Habitual knowledge remains inarticulate and unable to express itself. In a fundamental way it is anchored in our bodies and may be addressed as practical and enacted knowledge (Bourdieu 1993, 122-146). The shared Mongolian-Tibetan habitus is most obvious in the ontological perception of the natural environment which both Tibetans and Mongols imagine as enlivened space constituted of natural entities whose unpredictable energies and powers call for intersubjective interactions. In early modern Mongolian societies the acting out of such embodied knowledge was of crucial importance. To 'spread the dharma' first of all implied to carry into effect Buddhist rituals and practices and to inscribe them bodily, in loud recitations of Mantras and Dhāraṇis, in acts of bowing and throwing one's body to the earth etc. Further, in counteraction to the shamanic performance that always needs a public, the dharma also had to be performed publicly. The body itself became a visible marker of a Buddhist religious identity, and therefore both bodily performance and spatial presence were effective means to appropriate socio-religious power and prestige. The Buddhist monks provided additional and sometimes also new meanings to bodily engrained patterns of socio-religious knowledge, thereby slowly and subtly transforming existing practices and rituals. It is important to note that these new meaningful conceptions did not replace the older ones but were transformations of them.

The 'teaching of the shamans' was also addressed as (Mo.) qara šasin, 'black teaching', in binary opposition to (Mo.) sira šasin, 'yellow teaching', which the dGe lugs pa, the dominant Tibetan-Buddhist school in Mongolia, used as a 
self-referential designation in the Mongolian regions. Mongolian qara, 'black', is a highly inauspicious color among the Mongols. Therefore, normative assumptions underlie the narratives of the 'black teaching', authorizing and naturalizing a definition of shamans as a social group whose concepts and practices principally endanger their respective social communities, imagining them to apply negative forces to achieve their sinister aims. We know from Buddhist chronicles and the few shamanic prayers which have been written down that very soon shamans adopted and reconfigured this appellation, this time with a partly positive self-ascription: they associated 'black' with spiritual potency. From then on, black shamans were considered to be the most powerful ones, untouched by Buddhist concepts and practices. Yet at the same time they were believed to be potentially harmful to their communities. This ambivalent image of the 'black shaman' is still valid today (Heissig 1992, 205; Pedersen 2011, 76 and 88).

On the one hand the Mongolian discourse, structured by the terms üjel, nom

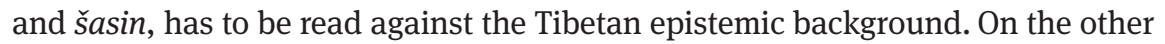
hand the Tibetan concepts that were transported by these terms were adjusted to their new communicative contexts. With regard to their respective contexts, the Tibetan terms have a broad semantic scope, but, as already explicated, most often they emphasize a well-ordered system of doctrines and teachings. Therefore, when the practices and rituals the shamans performed were appropriated as '[world]-view' or 'teaching' on the discourse level, this appropriation brought about a change in the Mongols' perception of socio-religious reality. The shamans were now treated as a distinct group which adhered to a fixed and stable corpus of rules, doctrines and practices, a development that is also attested in the afore-mentioned legal codes of the Qing Empire. Discourse and social structure are thus dialectically related, as discursive acts are simultaneously descriptive and constitutive of social reality. The degree of self-evidence the 'teaching of the shamans' had reached in the eighteenth century is particularly revealing in a short chronicle entitled 'History of the Ongyod "Black Protector"' (Mo. Ongyod qar-a sakizus-un teüke sudur bičig). Composed by an unknown author who must have had insider knowledge about shamanic lineages and narratives, the chronicle provides in an epic narrative an origin hypothesis for the emergence of shamans and shamanizing, making use of the term surtayun, literally 'that which is studied, science, rules, doctrine' (Lessing 1960, 740), to identify a 'doctrine of the female shamans' (Mo. udayun-u surtayun) (Anonymous 18th century, 4).

The discursively created religious tradition of the 'black teaching', or 'black faith', as the Buryat scholar Dorji Banzarov translated the term, is socially present in the religious specialists, the male and female shamans, but it excludes the lay people that in a Christian understanding build up a religious community. No 
Mongolian source from the Mongolian territories within the Qing Empire addresses lay people as building part of the social organization of the 'shamanic' tradition. The concept of lay-followers as opposed to religious specialists and the idea that both groups constitute a religious community of a specific persuasion has been extremely rare in early-modern Inner-Asian societies. The question of who belonged to which religious tradition was in most contexts not relevant outside the circle of religious specialists.

\section{European influences on Tibetan and Mongolian knowledge cultures}

Our Mongolian sources are curiously lacking in one important aspect. We have seen that since the late sixteenth century a shamanic view or teaching was singled out in discourse, the male and female shamans being the agents of this teaching. But what do we learn about the configuration of this teaching, about its doctrines, its practices, its ethics? All our primary sources from the Inner and Outer Mongolian territories do not provide any data about shamanic doctrines and practices, apart from the already mentioned healing and exorcizing practices. No text gives a detailed description of the concepts and practices that are evoked in the examined terms and statements. Even the article in the Kangxi law code of 1694 contains nothing concrete about the shamans. ${ }^{10}$ At a closer look, in the discourse of the Mongols of the Qing Empire, the 'teaching of the shamans' remains curiously opaque.

This changed only in the nineteenth century, in a different geographical and cultural environment. Siberian Buryat-Mongolia, the colonial backyard of the Russian Empire, provided a fertile ground for the encounter and entanglement of Tibeto-Mongolian and European knowledge cultures. Therefore, in the last part of my contribution I will explore how in the nineteenth century this Inner-Asian discourse was shaped by the encounter of European concepts. More concretely, I will follow up the discursive construction of the 'teaching of the shamans' in the text production of the Buryat-Mongols who were separated from the other Mongols by a political divide. Since around 1700, the Buryats living along the Eastern shores of Lake Baikal, in the Transbaikal regions, were Buddhists. They belonged to the greater Tibeto-Mongolian Buddhist cultural sphere that had its center in Lhasa, the capital of Tibet. At the same time, they were separated from this Buddhist universe by a political divide. The treaty

10 Contrary to its expressed focus, the article deals exclusively with the Buddhist community. 
of Kiakhta in 1727 had finally fixed the boundary lines between the Russian and the Qing Empire and had drawn an artificial border between the Mongols on each side (Perdue 2005, 161-173). Whereas in the Qing Empire Buddhism enjoyed state patronage from the emperors, who towards their Buddhist subjects acted as 'protectors of the dharma'11 and actively used Buddhism as a means to consolidate and legitimize their power (Berger 2003; Schwieger 2015), the Russian Empire favored the Christian Orthodox Church, and the Buddhists of the empire were confined to a marginal position (Tsyrempilov 2012). The simultaneous belonging to the Russian Empire and the greater Tibeto-Mongolian Buddhist world helped shape the Transbaikal regions into a complex amalgam of diverging cultural influences that contributed to the formation of the Buryat-Mongolian knowledge cultures. The Transbaikal Buryats constantly negotiated their self-perceptions and participation in these often conflicting worlds in visual and performative practices and in texts. Thus, the Russian Tsar was venerated by his Buddhist subjects as an emanation of the female bodhisattva White Tārā ${ }^{12}$ that traditionally has a close relationship to Avalokiteśvara, Tibet's most revered bodhisattva. In this way, on a visual and symbolic level, Tibet and Russia were inextricably linked together.

Like their Mongolian brethren across the borders, the Buryats put great efforts into writing down their history. Historical chronicles were wide-spread and popular especially in the nineteenth century. Their authors were most often people who worked in politically powerful, yet subaltern, positions in the Siberian colonial administration, the steppe duma, and, due to their social and educational background, participated both in the Tibeto-Mongolian and the Russian cultural spheres. I have analyzed two of these chronicles in regard to their literary relations and epistemic structures. The chronicle 'What happened in the past of the Qori- and Aga-Buriyads' (Mo. Qori kiged aruyin buriyad-nar-un urida-dayan bolursan anu) dates from 1863 and was composed by the ruling chief (taisha) of the Aga Buryats, Tügülder Toboyin (Toboyin 1863). The second chronicle, entitled 'Tale of the origin of the lineage of the people of the eleven fathers of the Qori' (Mo. Qori-yin arban nigen ečige-yin jun-u ur ijarur-un turuji), was written in 1875 by Vangdan Yum Čüng, an official of the Qori steppe duma (Yum Čüng 1875). Both chronicles contain chapters about the 'teaching of the shamans'. While the discourse on shamans in Inner and Outer Mongolia was shaped by the Indo-Tibetan and the indigenous Mongolian knowl-

11 The Qing commitment to Tibetan Buddhism tended to include only the dGe lugs pa, defining all other Tibetan-Buddhist schools as heterodox (Petech 1972, 106-107). The Tibetan dGe lugs pa government actively supported this politics (Schwieger 2015, 166-170).

12 This veneration is nowadays extended to the Russian president (Bernstein 2013, 1). 
edge cultures that mutually influenced each other, these chronicles also show distinct Russian influence. They are informed by three different epistemic models: In the tradition of Mongolian history writing they are genealogical accounts. By drawing on important Mongolian historical works, both authors place themselves firmly in the Mongolian historiographical tradition (Kollmar-Paulenz 2014b). Secondly, in separate chapters Toboyin and Yum Čüng provide systematic overviews of the religious traditions extant among the Buryats: that is Buddhism and the 'teaching of the shamans'. The chapters on the 'teaching of the shamans' follow, in structure and topic, Indo-Tibetan doxography, the so-called 'presentation of tenets' (Tib. Grub mtha'i rnam bzhag). In texts of this genre religio-philosophical schools, both non-Buddhist and Buddhist, are presented in a systematical way (including their historical development) that allows the Buddhist scholar to compare them with respect to their soteriological quality (Hopkins 1996). The genre had been already popular in India and was further developed in Tibet since at least the eleventh century. One doxography, bearing the title 'Crystal Mirror of good explanations, showing the sources and assertions of all systems of tenets' (Tib. Grub mtha' thams cad kyi khungs dang 'dod tshul ston pa legs bshad shel gyi me long) and written in 1802 by the Mongolian scholar Thu'u bkvan Blo bzang chos kyi nyi ma (1737-1802), a resident of dGon lungs monastery in Northeastern Tibet (Amdo), was particularly popular in the Buriyad regions (Thu'u bkvan Blo bzang chos kyi nyi ma 1802; Thuken Losang Chökyi Nyima 2009). A comparison of the two chronicles with this doxography brought to light that both Buryat authors closely follow this doxographical model to present knowledge (Kollmar-Paulenz 2014a). But there is, thirdly, one striking difference, and here Russian influence comes in: while Grub mtha' rnam bzhag texts focus almost exclusively on worldviews, both chronicles give much more attention to the shamanic actor, including his initiation, attire and practices. This focus on the agents of religious doctrines bears marked resemblance to eighteenth and nineteenth century Russian and German ethnographic accounts about North Asian 'shamanism' (Georgi 1776-1780; Pallas 1980) including Banzarov's famous work on the 'Black Faith'.

Furthermore, in Yum Čün's chronicle the 'teaching ${ }^{13}$ of the shamans' no longer refers exclusively to the religious specialists who constitute its semi-institutional social body, but also includes lay-followers. For the first time, the author speaks of (in literal translation) 'the people of the teaching of the shamans' (Mo. böge-nerün šasin-un ulus-nar) (Yum Čüng 1875, 92), or, as one Russian translator

13 Instead of šasin, he uses the term mörgöl comparatively, thus šasin mörgöl, 'Buddhism' (Yum Čüng 1875, 63), and böge-ner-ün mörgöl, 'Shamanism’ (Yum Čüng 1875, 91). 
more smoothly renders the phrase, 'the people of the shamanic faith' (Poppe 2011, 46). Thus, the semantic scope of the Mongolian šasin is once again transformed, this time including a Christian understanding of what constitutes a 'religious tradition'.

\section{Conclusion}

I have provided a short and rather sketchy insight into one particular aspect of Mongolian epistemic cultures in which reality is assessed by second-order categories that are socially constructed. The Indo-Tibetan taxonomies that had a specific emphasis on philosophy and epistemology, in the process of their integration into Mongolian epistemic cultures and their implicit ontologies, were renegotiated and came to include the inter-relational, visual and performative aspects that are addressed in the terms and the concepts of mörgöl, üjel and šasin that structure the Mongolian discourse. The narrative of 'shamanism' that gained dominance in the Mongolian societies since the late sixteenth century was the result of and simultaneously formed the politics of the local rulers and the newly emerging, powerful social class of the Buddhist sangha. The continuous reiteration of discursive and non-discursive, especially bodily, practices shaped the Mongols' perceptions of shamanic practices and Buddhist teachings alike. On the one hand, the interplay of Tibetan and Mongolian knowledge formations led to a reconfiguration of a Buddhism that was deeply shaped by Mongolian ontological perspectives. On the other hand, the shamans and their teachings emerged as a distinct social group with a fixed and stable set of practices and concepts, and 'shamanism' as a distinct religious tradition took shape in late sixteenth, early seventeenth century Mongolia. Thus, this case study shows religious traditions to be established as discursive formations, fields of statements and practices. Furthermore, and here I follow Gavin Flood, religious traditions are made up of collective representations, of fluid ensembles of cultural resources that in encounter situations are discursively condensed into distinct and stable entities (Flood 1999, 50 -51). This reification is initiated when cultural boundaries are crossed and rival religious actors compete, among other things, for material resources and social prestige. The emergence of religious traditions is also constitutive in relation to other forms of power, in our case the centralized polity of the Qing state and its alliance with the Buddhist sangha. Religious traditions are thus simultaneously the result of complex social, cultural and political processes and discursive constructions that shape them.

My case study has further theoretical implications. It has brought to light that the Mongolian taxonomic field of üjel, nom and ultimately šasin, the last 
term employed since the later eighteenth century in comparative contexts, singling out Buddhism and 'shamanism' as well as Islam and later Christianity as distinct and comparable fields of social interaction, can be meaningfully related to the European discourse field of 'religion'. This taxonomic field did not emerge in the encounter with Europe and a European concept of 'religion'. The historical legacy of the normative and theoretical concepts that shaped Mongolian perceptions of social reality lies in the complex entanglement of Mongolian ontological concepts and the rich epistemic cultures of Tibet. European notions of 'religion' started to inform the Tibeto-Mongolian conceptualizations only when Buddhism spread further north to the shores of Lake Baikal. It is important to note that this complex interplay of Tibetan, Mongolian and Russian epistemic cultures critically influenced our own scholarly discourse about 'shamanism' which took its distinct shape in the twentieth century. The Mongolian conceptualizations of 'shamanism' found their way into European academic scholarship ${ }^{14}$ through the mediation of Buryat scholars like Dorji Banzarov, Tsyben Zhamtsarano (Tolz 2015) and others. But already in earlier times, German and Russian ethnographers had reported about Mongolian and Buryat-Mongolian shamans, and partly they had done so using Mongolian taxonomies that had been formed in the confrontational encounters between Tibetan-Buddhist monks and Mongolian shamans since the late sixteenth century. A scientific study of religion that ignores non-European knowledge cultures in their historical dimensions is prone to overlook these multiple interactions and entanglements that took place long before the 'global' twentieth century. Indeed, in recent years the genealogy of eighteenth and nineteenth century European shamanism-discourse has been reconstructed by a couple of scholars, ${ }^{15}$ but these reconstructions have not included the non-Western discourses on the term and the concept, thus once more producing an 'intellectual map of the world' (Coronil 2002, 179) that excludes non-Western cultures. Following the project of a global history of religion, I suggest to explore the discursive configurations of the religious field in different cultural settings by paying due attention to the legacy of non-Western epistemic cultures, as today's multiple modernities are rooted in and shaped by a multitude of different historical knowledge cultures.

14 My use of the term 'European scholarship' includes, of course, Russian scholarship. 15 Flaherty 1992; Hutton 2001; Stuckrad 2003; Znamenski 2007. 


\section{Bibliography}

Anonymous 1607. Erdeni tunumal neretü sudur. Xeroxcopy of the manuscript preserved in the library of the Academy of Social Sciences. Hohot (PRC).

Anonymous $18^{\text {th }}$ century. Ongrod qara sakirusun teüke sudur bičig orosiba, Mong. 41. Royal Library Copenhagen.

Anonymous 1980. Qad-un ündüsün quriyangyui altan tobči. Kökeqota.

Bajarsajchan, B. 2004. Mongyol čayajin-u bičig. (Ėkh bičgüün sudalgaa). Tërgüün dèvtèr. Ulaanbaatar.

Banzarov, Dorji 1846. Chernaja vera ili shamanstvo u mongolov. V tipografii Imperatorskago Kazanskago Universiteta. Kazan.

Bawden, Charles R. 1961. The Jebtsundamba Khutukhtus of Urga. Text, Translation and Notes. Wiesbaden.

Berger, Patricia 2003. Empire of Emptiness. Buddhist Art and Political Authority. Honolulu. Bergunder, Michael 2011. 'Was ist Religion? Kulturwissenschaftliche Überlegungen zum Gegenstand der Religionswissenschaft', Zeitschrift für Religionswissenschaft 19. 3-55.

Bernstein, Anya 2013. Religious Bodies Politic. Rituals of Sovereignty in Buryat Buddhism. Chicago and London.

Bourdieu, Pierre 1993. Sozialer Sinn. Kritik der theoretischen Vernunft. Frankfurt am Main. Byamba Erke Dayičing 1667. Pringlai (ed.): Byamba. Asararči neretü-yin teüke. Ulaanbaatar 1960.

Chakrabarty, Dipesh 2000. Provincializing Europe. Postcolonial Thought and Historical Difference. With a new preface by the author. Princeton.

Chiodo, Elisabetta 2009. The Mongolian Manuscripts on Birch Bark from Xarbuxyn Balgas in the Collection of the Mongolian Academy of Sciences. Part II. Wiesbaden.

Conrad, Sebastian; Randeria, Shalini (eds.) 2002. Jenseits des Eurozentrismus. Postkoloniale Perspektiven in den Geschichts- und Kulturwissenschaften. Frankfurt.

Coronil, Fernando 2002. 'Jenseits des Okzidentalismus. Unterwegs zu nichtimperialen geohistorischen Kategorien.' In Jenseits des Eurozentrismus. Postkoloniale Perspektiven in den Geschichts- und Kulturwissenschaften, eds. Sebastian Conrad, Shalini Randeria. Frankfurt. $177-218$.

Dag yig mkhas pa'i byung gnas. Dag yig mkhas pa'i byung gnas zhes bya ba bzhugs so. Merged yarqu-yin oron neretü toytayaysan dayiy orosiba. Xylograph, Beijing. Private collection Prof. Dr. Richard Ernst (Winterthur).

Flaherty, Gloria 1992. Shamanism and the Eighteenth Century. Princeton.

Flood, Gavin 1999. Beyond Phenomenology. Rethinking the Study of Religion. London.

Georgi, Johann Gottlieb 1776-1780. Beschreibung aller Nationen des russischen Reichs, ihrer Lebensart, Religion, Gebräuche, Wohnungen, Kleidungen und übrigen Merkwürdigkeiten. 4th edition: Mongolische Völker, Russen und die noch übrigen Nationen. St. Petersburg.

Haenisch, Erich 1955. Eine Urga-Handschrift des mongolischen Geschichtswerks von Secen Sagang (alias Sanang Secen). Berlin.

Hallisey, Charles 1995. 'Roads Taken and Not Taken in the Study of Theravāda Buddhism.' In Curators of the Buddha, ed. Donald S. Lopez, Jr. The Study of Buddhism under Colonialism. Chicago. 31-61. 
Heissig, Walther 1992. Schamanen und Geisterbeschwörer in der östlichen Mongolei. Gesammelte Aufsätze. Wiesbaden.

Heuschert, Dorothea 1998. Die Gesetzgebung der Qing für die Mongolen im 17. Jahrhundert anhand des Mongolischen Gesetzbuches aus der Kangxi-Zeit (1662-1722). Wiesbaden.

Holbraad, Martin; Willerslev, Rane 2007. 'Transcendental Perspectivism: Anonymous Viewpoints from Inner Asia', Inner Asia 9.2. Special issue Perspectivism. 329-345.

Hopkins, Jeffrey 1983. Meditation on Emptiness. London.

Hopkins, Jeffrey 1996. 'The Tibetan Genre of Doxography: Structuring a Worldview.' In Tibetan Literature. Studies in Genre, eds. José I. Cabezón, Roger R. Jackson. Ithaca, NY. $170-186$.

Humphrey, Caroline 1999. 'Shamanic Practices and the State in Northern Asia: Views from the Center and Periphery.' In Shamanism, History, \& the State, eds. Nicholas Thomas, Caroline Humphrey. Ann Arbor, MI. 191-228.

Humphrey, Caroline 2003. 'Chiefly and Shamanist Landscapes in Mongolia.' In The Anthropology of Landscape. Perspectives on Place and Space, eds. Eric Hirsch, Michael O'Hanlon. Oxford. 135-162.

Humphrey, Caroline; Ujeed, Hurelbaatar 2013. A monastery in time. The making of Mongolian Buddhism. Chicago.

Hutton, Ronald 2001. Shamans. Siberian Spirituality and the Western Imagination. London.

Jimbadorji 1834-37. 'Bolor toli, Spiegel aus Bergkristall, von Jimbadorji (1834-37).' In Geschichte der Mongolen, Buch III, ed. Walther Heissig. Kopenhagen 1962.

Kämpfe, Hans Rainer 1976a. Ñi ma'i 'od zer / Naran-u gerel. Die Biographie des 2. Pekinger IČan் skya-Qutuqtu Rol pa'i rdo rje (1717-1786). St. Augustin.

Kämpfe, Hans Rainer 1976b. 'Die Biographie des 3. Pekinger Čań skya-Qutuqtu Ye šes bstan pa'i rgyal mc'an (1787-1846) - Aus der Biographiensammlung Čindamani-yin erikes in Faksimile herausgegeben, 1. Folge', Zentralasiatische Studien 10. 225-285.

Kämpfe, Hans Rainer 1977. 'Die Biographie des 3. Pekinger Čań skya-Qutuqtu Ye šes bstan pa'i rgyal mc'an (1787-1846) - Aus der Biographiensammlung Čindamani-yin erikes in Faksimile herausgegeben, 2. Folge', Zentralasiatische Studien 11.121-131, text facsimile $132-175$.

Kämpfe, Hans Rainer 1979a. 'Sayin qubitan-u süsüg-ün terge. Biographie des 1. rJe bcun dam pa-Qutuqtu Öndür gegen (1635-1723), verfasst von Nag gi dbań po 1839, 1. Folge', Zentralasiatische Studien 13. 93-136.

Kämpfe, Hans Rainer 1979b. 'Sayin qubitan-u süsüg-ün terge. Biographie des 1. rje bcun dam pa-Qutuqtu Öndür gegen (1635-1723), verfasst von Nag gi dbań po 1839, 2. Folge’, Zentralasiatische Studien 15. 331-382.

Kämpfe, Hans Rainer 1983. Das Asaragči neretü-yin teüke des Byamba erke daičing alias Šamba jasay. Eine mongolische Chronik des 17. Jahrhunderts. Wiesbaden.

Kas'yanenko, Zoya K. 1993. Katalog peterburgskogo rukopisnogo "Гanzhura”. Sostavlenie, vvedenie, transliteraciya i ukazateli. Moskva.

Khams smyon 'Jigs bral chos kyi seng ge 1974. Zhi byed dang gcod yul gyi chos 'byung rin po che'i phreng ba thar pa'i rgyan. In gCod kyi chos skor. Three Texts on the History and Practice of the Źi-byed and Gcod Precepts. Reproduced from rare blockprints from the Library of Tibet House. Śer phyin tshigs bcad chen mo of Āryadeva, Phun po gzan skyur gyi rnam bśad, źi byed dan Gcod yul gyi chos 'byun of Jigs-bral-chos-kyi-senge. New Delhi. 
Kollmar-Paulenz, Karénina 2010. 'Mongolische Geschichtsschreibung im Kontext der Globalgeschichte.' In Geschichten und Geschichte, eds. Peter Schalk et al. Uppsala. 247-279.

Kollmar-Paulenz, Karénina 2012. 'A method that helps living beings: How the Mongols created "Shamanism", Mongolo-Tibetica Pragensia 12, 5/2. 7-19.

Kollmar-Paulenz, Karénina 2013. 'Lamas und Schamanen: Mongolische Wissensordnungen vom frühen 17. bis zum 21. Jahrhundert. Ein Beitrag zur Debatte um aussereuropäische Religionsbegriffe.' In Religion in Asien? Studien zur Anwendbarkeit des Religionsbegriffs, eds. Peter Schalk et al. Uppsala. 151-200.

Kollmar-Paulenz, Karénina 2014a. 'Systematically Ordering the World: The Encounter of Buriyad-Mongolian, Tibetan and Russian Knowledge Cultures in the 19th Century.' In L'orientalisme des marges: éclairages à partir de l'Inde et de la Russe, eds. Philippe Bornet, Svetlana Gorshenina. Etudes de Lettres 2-3. 123-146.

Kollmar-Paulenz, Karénina 2014b. ‘Vstrecha burjat-mongol'skoj, tibetskoj i russkoj kul'tur znanija.' In Buddizm v istorii i kul'ture burjat, ed. I.R. Garri. Ulan-Ude. 304-325.

Landwehr, Achim 2008. Historische Diskursanalyse. Frankfurt.

Lessing, Ferdinand D. 1960. Mongolian-English Dictionary. Compiled by Mattai Haltod, John Gombojab Hangin, Serge Kassatkin, Ferdinand D. Lessing. Berkeley.

Ligeti, Louis 1942. Catalogue du Kanjur Mongol Imprimé. Vol. I. Budapest.

Lopez, Donald S. 1996. 'Polemical Literature (dGag len).' In Tibetan Literature. Studies in Genre, eds. José I. Cabezón, Roger R. Jackson. Ithaca, NY. 217-228.

Lubsandanjin 1655. Altan Tobči. A Brief History of the Mongols by bLo-bzan bstan- jin with A Critical Introduction by the Reverend A. Mostaert and An Editor's Foreword by F.W. Cleaves. Cambridge, MA, 1952.

Mergen Gegen 2006. Včir dhara mergen diyanči blam-a-yin gegen-ü gbum jarliy kemegdekü orosiba, vol. 5. Kökeqota.

Ngag dbang blo bzang rgya mtsho 1984. rJe btsun thams cad mkhyen pa bsod nams rgya mtsho'i rnam thar dngos grub rgya mtsho'i shing rta. In 'Phags pa 'jig rten dbang phyug gi rnam sprul rim byon gyi 'khrungs rabs deb ther nor bu'i 'phreng ba. Dharamsala. Vol. 2. 1-171.

Pallas, Peter Simon 1980. Sammlungen historischer Nachrichten über die mongolischen Völkerschaften, 2 Theile. Um eine Einführung vermehrter Nachdruck der 1776 und 1801 bei der Kaiserlichen Akademie der Wissenschaften in St. Petersburg erschienenen Ausgabe. Mit einer Einführung von S. Hummel. Graz.

Pedersen, Morten Axel 2011. Not Quite Shamans. Spirit Worlds and Political Lives in Northern Mongolia. Ithaca.

Perdue, Peter C. 2005. China marches West. The Qing Conquest of Central Eurasia. Cambridge.

Pernau, Margrit 2007. 'Transkulturelle Geschichte und das Problem der universalen Begriffe. Muslimische Bürger im Delhi des 19. Jahrhunderts.' In Area Studies und die Welt. Weltregionen und neue Globalgeschichte, ed. Birgit Schäbler. Wien. 117-149.

Petech, Luciano 1972. China and Tibet in the early XVIIIth Century. History of the establishment of Chinese protectorate in Tibet. Leiden.

Poppe, Nikolaj. 2011. 'Vandan Jumsunov. Istorija proiskhozhdenija odinadtsati khorinskikh rodov.' In Burjatskie letopisi, ed. Tsymzhit P. Vanchikova. Ulan-Ude. 32-81. 
Prajñasagara 1739. Boyda neyiči toyin dalai mañjusryi-yin domoy-i todorqai-a geyigülügči čindamani erike kemegdekü orosiba. Xylograph, Beijing.

Rachewiltz, Igor de 1996. The Mongolian Tanjur Version of the Bodhicaryāvatāra. Edited and Transcribed, with a Word-Index and a Photo-Reproduction of the Original Text (1748). Wiesbaden.

Rasipungsuy 1774/75. Bolor Erike. Mongolian Chronicle by Rasipungsuy with a Critical Introduction by the Reverend Antoine Mostaert, C.I.C.M., Arlington, Virginia and An Editor's Foreword by Francis Woodman Cleaves, Professor of Far Eastern Languages, Harvard University. 5 vols. Cambridge, MA, 1959.

Sagaster, Klaus 2007. 'The History of Buddhism among the Mongols.' In The Spread of Buddhism, eds. Ann Heirman, Stephan Peter Bumbacher. Leiden. 379-432.

Schwieger, Peter 2015. The Dalai Lama and the Emperor of China. A Political History of the Tibetan Institution of Reincarnation. New York.

Siluyun budayun üye onoqui neretü sudur. Translated by Toyin Guosi. Manuscript, Ulaanbaatar, private collection.

Siregetü Guosi Dharma 1739. Altan kürdün mingyan gegesütü bičig. Eine mongolische Chronik von Siregetü Guosi Dharma (1739). Hg. und mit Einleitung und Namensverzeichnis versehen von Walther Heissig. Kopenhagen 1958.

Stuckrad, Kocku von 2003. Schamanismus und Esoterik: Kultur- und wissenschaftsgeschichtliche Betrachtungen. Leuven.

Thuken Losang Chökyi Nyima 2009. The Crystal Mirror of Philosophical Systems. A Tibetan Study of Asian Religious Thought. Translated by Geshé Lhundub Sopa. Edited by Roger R. Jackson. Boston.

Thu'u bkvan Blo bzang chos kyi nyi ma 1802. Grub mtha' thams cad kyi khungs dang 'dod tshul ston pa legs bshad shel gyi me long. Indian reprint in pothi-format.

Toboyin 1863. 'Khronika Tugultur Toboeva 1863 g. Qori kiged aruyin buriyad-nar-un urida-daran bolursan anu.' In Letopisi khorinskikh buriat, vyp. I. Khroniki Turultur Toboeva i Vandana lumsunova, ed. Nikolaj N. Poppe. Moskva 1935.1-47.

Tolz, Vera 2015. 'Reconciling Ethnic Nationalism and Imperial Cosmopolitanism: The Lifeworlds of Tsyben Zhamtsarano (1880-1942)', Asiatische Studien/Études Asiatiques 69/3. $723-746$.

Tsyrempilov, Nikolay 2012. “'Alien” Lamas: Russian Policy towards Foreign Buddhist Clergy in the Eighteenth to Early Twentieth Centuries', Inner Asia 14. 245-255.

Van der Veer, Peter 2001. Imperial Encounters. Religion and Modernity in India and Britain. Princeton.

Vanchikova, Ts. P. 2001. Čayan teüke - “Belaja istorija” mongol'skij istoriko-pravovoj pamjatnik XIII-XVI vv. Sostavlenie kriticheskogo teksta i perevod "Beloj istorii” P.B. Baldanzhapova, issledovanie, redaktirovannie perevoda, sostavlenie kommentariev, podgotovka teksta "Beloj istorii" k publikatsii, perevod i kommentarij k "Shastre khana-chakravartina" i "Shastre Orunga” Ts. P. Vanchikovoj. Ulan-Ude.

Ye shes rdo rje 1959. Bod skad kyi brda' gsar rnying dka'ba sog skad du kā li sum cu'i rim pas gtan la pheb pa'i brda' yig mkhas pa rgya mtsho blo gsal mgul rgyan ces bya ba bzhugs so. Ulaanbaatar.

Young, Robert J.C. 2010. Postcolonialism. An historical introduction. Blackwell. 
Yum Čüng 1875. 'Khronika Vandana lumsunova 1875 g. Qori-yin arban nigen ečige-yin jun-u

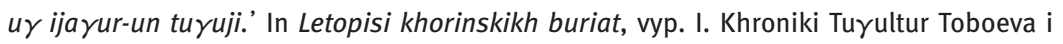
Vandana lumsunova, ed. Nikolaj N. Poppe. Moskva, Leningrad 1935. 48-172.

Zhang Yisun 1985. Bod rgya tshig mdzod chen mo. Zang han da cidian, 3 vols. Beijing. Znamenski, Andrei A. 2007. The Beauty of the Primitive. Shamanism and the Western Imagination. Oxford.

\section{Karénina Kollmar-Paulenz}

Institute for the Science of Religion, Faculty of Humanities

Bern University

Lerchenweg 36, Postfach

3000 Bern 9

Switzerland

karenina.kollmar-paulenz@relwi.unibe.ch 